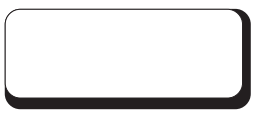

\title{
アルコールと脳内微量元素
}

\author{
鈴木裕 \\ 日本大学医学部内科学系神経内科学分野
}

\section{Alcohol and Trace Elements in the Brain}

\author{
Yutaka SuZuKI \\ Division of Neurology, Internal Medicine, Nihon University School of Medicine
}

\begin{abstract}
When men drink excessive amounts of alcohol over a prolonged period, they may develop neurological diseases, such as peripheral neuropathy, Wernicke encephalopathy, and alcohol-induced cerebellar degeneration. Trace elements in the brain can lead to the increased expression of receptors, enzymes for the synthesis and metabolism of the neurotransmitter, and proteins that modulate function, ets. It is possible that various neurological symptoms occur when trace elements in the brain are affected by excessive consumption of alcohol, even though the trace elements in the brain are maintained at a constant level. Drinking excessive levels of alcohol increases the level of zinc in the brain, while lower levels of zinc in blood are seen in men with signs of chronic excessive alcohol consumption, such as with alcoholic cirrhosis. It is speculated that increased free radicals by acute alcoholic intake, cause zinc to be increased in the brain in response to this phenomenon. Copper is closely related to neurological diseases, such as Wilson's disease or Menkes disease, but there have been no reports regarding encephalopathy induced by changes in copper and its metabolites in the brain due to drinking. About $80 \%$ of manganese in the brain exists within the astrocytes, and is involved in glutamine metabolism. However, there have not been many reports concerning the relation between alcohol and manganese. Low levels of manganese in the blood are observed in chronic alcoholics and these patients exhibit delirium tremens, tetany, convulsions, athetosis and involuntary movement. The level of iron in the blood increases with chronic excessive alcohol drinking, but there have been no reports indicating that iron levels in the brain are modified by alcohol intake. Metal-lothionein (MT) contributes significantly to zinc and copper metabolism and functions as a protective protein, but MT in the brain is increased when the MT-I overexpressing transgenic mouse (MT-I*) is administered $4 \mathrm{~g} / \mathrm{kg}$ of ethanol by a gastric tube. Acute ethanol administration can generate oxygen free radicals and cause oxidative stress in the brain. The mechanism of induction of MT in the brain after oral ethanol administration may be associated with oxidative stress caused by ethanol or its metabolites, and can be considered a protective mechanism against ethanol toxicity.
\end{abstract}

Key words: Alcohol, Encephalopathy Trace Elements, Zinc, Copper, Metallothionein アルコール , 脳内微量要素 , 亜鉛, 銅, メタロチオネイン

(J. Nihon Univ. Med. Ass., 2008; 67 (1): 7-10)

\author{
はじめに \\ アルコールと人との関係は紀元前 5000 年からとも \\ 7000 年からともいわれ，長い歴史を有する . 適度な飲酒 \\ は, 食欲増進, 快適な睡眠, 精神的緊張の緩和, 人間関 \\ 係を円滑にするなど有益なことが多い.しかし, 過量に \\ なると諸藏器に障害をもたらす．神経系では末梢神経障 \\ 害, Wernicke 脳症, アルコール性小脳変性症などがよく \\ 知られている. \\ 一方，生体は，すべて元素から成り立っており，体重 \\ の 99.4\%の常在元素 (酸素, 炭素, 水素, 室素, カルシ \\ ウム , リンなど) と $0.6 \%$ 微量元素からなる.鉄は体内
}

に3-5 g 存在し，これよりも少ないものを微量元素とい う. 微量元素は 23 種類あるが, 必須の微量元素は鉄, 銅, 亜鉛, マンガン, セレン , ヨウ素, モリブデン, ク ロム, コバルトの 9 種類である .この微量元素は生命の 維持，発育のために正常な生理機能を保つために働いて いる．脳内では神経伝達物質の代謝，合成，神経伝達物 質の受容体の発現, 機能調節などに関係している. 微量 元素は細胞内代謝や細胞応答に関与する種々の酵素やホ ルモンなどの活性に関わっているため, 一定のバランス が保つように維持されている．しかし何らかの原因で過 乗になったり，あるいは欠乏したりすると諸蔵器に影響 がでてくる．乥こでアルコールによって多くの神経疾患 
が引き起こされるが, アルコールと脳内微量元素につい てどのような関係があるのかについて検討してみた .さ らに微量元素ではないが亜鉛や銅代謝と密接に関連し， 話題の一つになっているメタロチオネイン (MT) につい ても言及してみた . なお本文中ではアルコールはエタ ノールの意味で用いた .

\section{I. アルコールと脳内微量元素}

アルコールの多量摂取者では各種栄養素の不足や吸収 障害などによりビタミン, 電解質ばかりでなく微量元素 にも変化が生じてくる. 兴の原因としては, アルコール や炎の代謝産物のアセトアルデヒドの直接作用および肝 などの諸藏器障害か関与しているものと思われる . 脳内 の微量元素か変化すると種々の神経症状が惹起される可 能性がある .

\section{a. 亜 鉛}

ヒトの脳内亜鉛濃度は約 $10 \mu \mathrm{g} /$ 湿重量で, 鉄に次いで 多(微量元素である1)。DNA 合成, RNA 合成, ステロ イドホルモン，成長ホルモンなどの受容体の遺伝子発現 など多くの物質代謝に関与している. 亜鉛欠乏では腸性 肢端皮膚炎，味覚障害がよく知られている. 亜鉛は神経 系では海馬, 扁桃体に多く存在し情報伝達物質として作 用するが, 脳虚血時には細胞から細胞外にでて中枢神経 障害を生じる ${ }^{2)}$. Kasarskis らは慢性のアルコール摂取者 の剖検脳では脳内各部位の亜鉛が正常脳に比べて 1520\%低下していたと報告した ${ }^{3)}$. 乥こでラットに3 3 ケ間 アルコール含有食 (自由摂取) を与える実験を行ってみた が脳内亜鉛には変化がなかったという.一方, アルコー ル性肝硬変などのアルコールの慢性多量摂取者では低亜 鉛血症がみられるとの報告が多い：この低亜鉛血症は， 亜鉛の吸収障害 , 肝での貯増亜鉛の低下，尿中亜鉛の排 泄増加など多くの要因関与していると思われる .これ らのことから慢性アルコール摂取者の脳内亜鉛の低下は 肝不全による血清业鉛の低下による 2 次的なものと考え られる . しかし高濃度のアルコール摂取は脳内亜鉛の濃 度を直接的に変化させる可能性があると思われる．筆者 らはマウスにアルコールを経管チューブを用いて急性に 大量に捸取させると海馬や小脳などの亜鉛は増加するこ とを示した ${ }^{4)}$. 急性アルコール摂取によりフリーラジカ ルが発生し，これに反応して脳内亜鉛か増加したと推測 されるが, 詳細な機序は不明である.しかし今のところ 急性の大量のアルコール攝取者で脳内亜鉛が変化したと いう報告はない .

\section{b. 銅}

銅は生体内でエネルギ一産生，カテコラミンの代謝， 抗酸化作用に関与する. 電子伝達 (チトクローム $\mathrm{c}$ オキ シダーゼ), 神経伝達物質の整合性 (ドパミン $\beta$ ヒドロ
キシラーゼ), 活性酸素の除去 (スーパーオキシドジスム ターゼ)などに関与する酵素に必要である、銅代謝異常 の代表的な神経疾患にはWilson 病, Menkes 病がある . Menkes 病では，著明な銅欠乏がみられ，チトクローム c オキシダーゼ活性が低下する．脳萎縮が著明で精神運 動発達遅延，失調，痙攣などがみられる．また最近では 銅はアルツハイマー病や筋萎縮性硬化症などとも関連し ている5,6) といわれ，銅の代謝は神経疾患と密接に関係し ていると思われる．多量飲酒者の血清銅は，高值，正 常，低値のいずれの報告もあるが，高值をみとめるとい う報告が多い．またアルコール性肝硬変者では肝内銅含 有量増加がみられるという．消化管からの銅の吸収六 進，肝細胞から総胆管への排泄障害，肝細胞内での銅代 謝異常などが原因と考えられている．しかしマウスに経 管チューブを用いて急性に大量にアルコールを㩒取させ ても脳内の各部位の銅濃度には変化がなかった ${ }^{4)}$. また 人でも飲酒による脳内銅濃度の变化や銅代謝異常による 脳症は報告がない．

\section{c. マンガン}

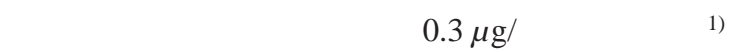
脳内マンガンの $80 \%$ はアストロサイトに存在し , グルタ ミン代謝に関与しているといわれている．マンガンの粉 塵吸入をすると大脳基底核にマンガンが集積し, ドーパ ミン作動性神経路に障害を生じ , パーキンソンニズムが 生じることはよく知られている．マンガン欠乏症の報告 は少ないが，てんかんとの関連性を指摘する報告もあ る . アルコールとマンガンとの関係に関する報告は多く ない . ラットにアルコールを慢性的に捸取させると肝で のマンガンは増加するが脳内マンガンは変化がなかっ た7) との報告がある．また，アルコール依存症で血清， 尿中マンガンが高值を示した8) いう報告もある .

\section{d. セレン}

ヒトの脳内セレン濃度は約 $0.2 \mu \mathrm{g} / \mathrm{g}$ である ${ }^{8)}$. 脳内セ レンはドーパミン伝達経路で濃度が高( ${ }^{18)}$. アルコール を摂取するとフリーラジカルが発生し10)，これに対して 生体内では防御機構が働く. Glutathione (GSH) peroxidase がこの中心的役割を果たすが，セレンはこの酵素の 補酵素として働く.多量飲酒者では血清セレンの低下が 起きる. 詳細な機序は不明であるがアルコールの直接作 用ではないかといわれている .この血清セレンの低下に より GSH peroxidase 活性の低下が生じ，血清過酸化脂 質か増加して細胞障害を生じる．しかし，セレン欠乏時 でも脳は他の藏器と異なりセレン濃度保持機構にすぐ れ, 脳内セレン濃度は低下しにくいといわれている.セ レンに関連した脳症の報告はない．

\section{e. $\mathrm{Mg}$}

慢性多量飲酒者では食事による $\mathrm{Mg}$ の摂取不足や胃， 
小腸による吸収障害, 尿中 $\mathrm{Mg}$ の排泄増加などにより低 $\mathrm{Mg}$ 血症となり，特に神経系に影響を及ぼす。振戦せん 妄, テタニー, けいれん, アテトーゼや舞踏病樣不随意 運動などが生じる11)。抑うつ, 不安, 興奮などの精神症 状も生じる . 硫酸 $\mathrm{Mg}$ の投与で不随意運動などは改善す る.この低 $\mathrm{Mg}$ 血症には低 Ca 血症を伴うため, 神経症 状は低 $\mathrm{Ca}$ 血症に起因しているという説もある ${ }^{12)}$.

\section{f. 鉄}

鉄は体内に $3-5 \mathrm{~g}$ 存在する . 脳内ではドパミンと分布 か類似している、特に線条体，黑質に多く存在する。脳 内細胞の中ではオリゴデンドロサイトに多く, 神経系の 発達に重要な役割を果たす.髄鞘の形成, 樹状突起形 成, 神経伝達物質合成, エネルギー産生などに関与して いる.貧血が著明な母体からの出生児は海馬, 線条体の 障害があり認知機能障害, 記憶が障害される . 成人で は，鉄が欠乏すると夜間に足がむずむずする下肢静止不 能症候群が発症することがある.慢性多量飲酒者では血 中鉄は増加するが, これはアルコール摂取で胃酸分泌が 盛んになり，小腸での水溶性が増大し鉄吸収が促進する ためである．また赤ワインには多量に鉄が含まれており これも一因となる．ヒトの脳内鉄濃度は約 60-70 $\mu \mathrm{g} /$ 湿 重量である1).鉄は脳内の老人班形成に関与したりフ リーラジカル産生に関与するため, 脳内の鉄沈着とアル ツハイマー病やパーキンソンニズムとの関係も指摘され ている(13,14) . アルコール摂取で脳内鉄か変化したという 報告はない．

\section{II. アルコールと脳内メタロチオネイン}

メタロチオネイン (MT) はシステインに富んだ低分子 （分子量約 6000-7000）の蛋白質で動植物など自然界に広 く存在し, 生体の防御機構に関わっているといわれてい る.当初, MT はカドミウム $(\mathrm{Cd})$ 結合蛋白質として単離 され，金属に強い親和性を示すことで知られた。重金属 の解毒作用, 亜鉛や銅などの代謝調節, フリーラジカル 消去能などを有するといわれている.今までに 4 種の亜 型 (MT-I, II, III, IV) か確認されている (Table 1) . 兴のう ち神経系に特異的に発現する MT-III が発見されてから， 神経系での研究も盛んに行われてきている.MT の神経 系での機能の詳細は不明であるが, Table 2 のようもの が推測されている.MT は神経系では灰白質の約 $20 \%$ を 占めるアストロサイトに多く存在する ${ }^{15)}$. アストロサイ 卜は神経終末に多く存在し, 神経の情報伝達の調整や神 経細胞の保護作用などの働きをしている . 従ってアスト ロサイトの機能と MT は密接に関与していることか推測 される.飲酒すると肝だけでなく脳でもフリーラジカル が発生する ${ }^{10)}$ が , これはフリーラジカル scavenger であ るグルタチオン $(\mathrm{GSH})$ とシステインがアルデヒドの毒性 を消去するためにアルデヒドと結合し , フリーラジカル
Table 1 Metallothionein (MT) の存在部位

\begin{tabular}{ll}
\hline MT-I & 上皮系細胞 \\
MT-II & 上皮系細胞 \\
MT-III & 中枢神経系, 泌尿生殖器系? \\
MT-IV & 表皮, 舌, 食道などの扁平上皮 . 泌尿生殖器系?
\end{tabular}

Table 2 推測される Metallothionein (MT) の生理作用

1. 重金属の除去作用

2. 亜鉛結合蛋白質の生合成と活性の制御

3. カテコラミンや GABA 系神経伝達物質の調整

4. 銅や亜鉛などの重金属の再分布

5. 酸化的ストレスからの細胞防御作用

処理能が減少するためと考えられている．脳は肝蔵など と比べるとフリーラジカルの処理機構が弱いといわれて いるが , フリーラジカルが発生すると , 脳内でもこれに 反応して , システインに富む MT か増加すると推測され ている.実際，アルコールを MT-I 発現過剩マウス (MTI*) に経口投与させると, 脳内 MT か増加する4) . またア ストロサイトの培養細胞では MT 含量が多いほうがフ リーラジカル scavenger の機能か強く働く ${ }^{16)}$.これらのこ とからフリーラジカルが発生して生じる脳症や神経疾患 では, MTが重要な役割を果たしていることが推測され る . 人でも多量に飲酒すると脳内 MT の増加が予想され るが , 現時点でこのことを検討した報告はされていな い。

\section{結 論}

アルコールと脳内微量元素およびMT の関係について 概説した .これらに関する報告は多くはないが，アル コール多量摂取者では微量元素の絶対的な捸取不足，代 謝異常およびアルコール捸取によるフリーラジカル発生 に反応して脳内微量元素や MT か変化するのではないか と思われる。しかし詳細な機序は不明であり，これから の検討が望まれる .

\section{文献}

1) 武田厚司 . 脳におけるセレン微量金属の動態と役割に関 する研究 . Biomedical Research on Trace Elements 1988; 9 (1): 1-11.

2) Koh JY, Suh SW, Gwag BJ, et al. The role of zinc in selective neuronal death after transient global cerebral ischemia. Science 1996; 272 (5264): 1013-1016.

3) Kasarskis EJ, Manton WI, Devenport LD, et al. Effects of alcohol ingestion on zinc content of human and rat central nervous systems. Exp Neurol 1985; 90: 81-95.

4) Suzuki Y, Cherian MG. Effect of ethanol on brain metallothionein in transgenic mice. Alcohol Clin Exp Res 2000; 24: 315-321.

5) Squitti R, Lupoi D, Pasqualetti P, et al. Elevation of serum copper levels in Alzheimer's disease. Neurology 2002; 22; 59 (8): 1153-1161. 
6) Llanos RM, Mercer JF. The molecular basis of copper homeostasis copper-related disorders. DNA Cell Biol 2002; 21 (4): 259-270.

7) Bogden JD, Al-Rabiai S, Gilani SH. Effect of chronic ethanol ingestion on the metabolism of copper, iron, manganese, selenium, and zinc in an animal model of alcoholic cardiomyopathy. J Toxicol Environ Health 1984; 14 (2-3): 407-417.

8) 桂城俊夫, 高橋竜哉, 渋谷克彦, 他. 特異な MRI と血 清・尿中マンガン高值を示したアルコール依存症の一 例。神奈川県精神医学会，1996; 46: 59-63.

9) 渡辺知保. 脳におけるセレン : 特異的機能はあるのか? Biomedical Research on Trace Elements 2001; 12 (3): 197206.

10) Montoliu C, Valles S, Renau-Piqueras J, et al. Ethanol-induced oxygen radical formation and lipid peroxidation in rat brain: effect of chronic alcohol consumption. J Neurochem 1994; 63: $1855-1862$.

11) Flink EB. Magnesium deficiency. Etiology and clinical spec- trum. Acta Med Scand Suppl 1981; 647: 125-137.

12) Fankshen D, Raskin D, Dimich A, et al. The significance of hypomagnesemia in alcoholic patients. Am J Med 1964; 37: 802-812.

13) Ehmann WD, Markesbery WR, Alauddin M, et al. Brain trace elements in Alzheimer's disease. Neurotoxicology 1986; 7 (1): 195-206.

14) Good PF, Olanow CW, Perl DP. Neuromelanin-containing neurons of the substantia nigra accumulate iron and aluminum in Parkinson's disease: a LAMMA study. Brain Res 1992; 593 (2): 343-346.

15) Aschner M. Astrocyte metallothioneins (MTs) and their neuroprotective role. Ann N Y Acad Sci 1997; 825: 334-347.

16) Suzuki Y, Apostolova MD, Cherian MG. Astrocyte cultures from transgenic mice to study the role of metallothionein in cytotoxicity of tert-butyl hydroperoxide. Toxicology 2000; 145: $51-62$. 